\title{
EDUCAÇÃO E PUBLICIDADE
}

Luiz Carlos Carneiro de Faria e Souza

Sociólogo, Pesquisador do Núcleo de Estudos em Arte, Mídia e Política da PUC-SP

\begin{abstract}
Resumo: Nesse trabalho, procurou-se analisar a publicidade televisiva dirigida ao público adolescente-juvenil. Dentre todas as mídias, escolheu-se a TV, por ser a mais significativa de todas. O objetivo da publicidade, hoje, além da venda de produtos, serviços e bens simbólicos, é de demonstrar modelos a serem seguidos. Desta forma, ela apresenta um objetivo explícito, que consiste em oferecer as vantagens de determinados produtos, e um objetivo implícito, por intermédio do qual flui sua ação pedagógica.

Palavras-chave: publicidade e jovens; televisão e educação.
\end{abstract}

$\mathrm{D}$ entre todas as mídias veiculadoras de publicidade na contemporaneidade, a televisão é a mais significativa de todas. Sua participação na verba publicitária, em 1996, atingiu 59\% do total dos investimentos feitos no período (Meio \& Mensagem, 1997). Por outro lado, a televisão é o veículo de comunicação que obtém maior receptividade junto aos jovens. Isto ficou evidenciado na pesquisa realizada pela agência norte-americana D'Arcy, Masius, Benton \& Bowles que, juntamente com seus associados, consultou jovens de 26 países, das classes A e B, em uma amostra de 6.547 adolescentes. No Brasil, o segmento estudado limitou-se às cidades de São Paulo e Rio de Janeiro, abrangendo 448 alunos de colégios particulares (Veja, 1995). Um dos resultados alcançados pela pesquisa é que não existem praticamente diferenças entre os jovens globais que pertençam ao mesmo nível socioeconômico, sendo que um dos motivos para esta situação refere-se ao fato de que a globalização se opera sobretudo via televisão, que foi apontada como o passatempo de $93 \%$ dos pesquisados.

Neste sentido, este artigo ${ }^{1}$ tomou por base de análise uma pesquisa cuja finalidade foi caracterizar o adolescente em sua origem familiar, sua vida cotidiana, seu relacionamento com os meios de comunicação, informação e mídia, sua interação com a publicidade, bem como o "reconhecimento" que ele faz de alguns filmes publicitários, após a projeção a que assistiram.
O universo pesquisado foi o público adolescente-juvenil, isto é, na faixa etária entre 12 e 18 anos. $^{2}$ Em se tratando de um público que apresenta um grau mais elevado de compreensão dos objetivos da publicidade e seguindo as tendências teóricas vigentes tanto na área da comunicação quanto na área das ciências sociais (sobretudo a antropologia), preocupou-se com o receptor em sua interação com a comunicação: um consumidor que possui seu espaço de produção cultural e, enquanto ator social, a partir de seu conhecimento e subjetividade, reelabora os conteúdos das mensagens oriundas de um emissor. Por outro lado, procurou-se não desvincular o estudo da recepção dos processos de produção.

Os questionários foram respondidos por 95 alunos, sendo que $88,2 \%$ deles estavam na faixa de 15 a 18 anos, $43 \%$ eram do sexo masculino e $57 \%$ do feminino. Das três instituições de ensino que participaram dessa pesquisa, duas localizam-se no Município de São Paulo, em bairros de classe média (Escola Estadual de 2ํㅡ Grau Brasílio Machado) e média-alta (Escola Nossa Senhora das Graças) e a terceira no município de Carapicuíba, em uma região periférica caracterizada como cidade-dormitório (Escola Estadual de 1ํ e 2o Graus Dr. Benedito de Lima Tucunduva). As três salas sorteadas para constarem da amostra correspondem à primeira série do ensino médio.

Quanto à faixa etária, a Escola Brasílio apresenta a menor média de idade (14,1 anos), seguida pela Escola das 
Graças (14,6 anos), ambas com o menor desvio padrão. $\mathrm{Na}$ Escola Tucunduva, a média de idade é de 19,9 anos e o maior desvio padrão decorre do significativo intervalo que oscila dos 15 aos 34 anos. No cômputo geral, a média é de 15,9 anos.

A quase totalidade dos estudantes $(88,2 \%)$ situa-se na faixa etária dos chamados adolescentes (15 a 18 anos), $7,5 \%$ são jovens (19 a 25 anos) e 4,3\% adultos (26 anos ou mais). Entre os adolescentes, $43 \%$ são do sexo masculino e $57 \%$ do feminino, sendo que a faixa etária dos homens alcançou 16,8 anos, contra 15,2 para as mulheres. A Escola Brasílio registrou o menor percentual de estudantes do sexo masculino $(38,9 \%)$ e a Escola das Graças, o mais significativo $(48,4 \%)$.

Dentre os entrevistados, 18 trabalhavam e 75 apenas estudavam. Na Escola das Graças, a totalidade dos alunos não exercia outra atividade, enquanto na Escola Brasílio e na Escola Tucunduva, 11,1\% e 53,8\%, respectivamente, trabalhavam.

No Gráfico 1, foi sobreposta a distribuição dos que trabalham com o nível de renda de cada instituição. Para a Escola Tucunduva, o percentual dos que trabalham seria bem mais elevado se houvesse um número maior de presença em sala de aula quando do preenchimento dos questionários.

\section{GRÁFICO 1}

Média do Indicador ABA-Abipeme (1) e Distribuição de Trabalhadores, por Escola

Região Metropolitana de São Paulo - 1997
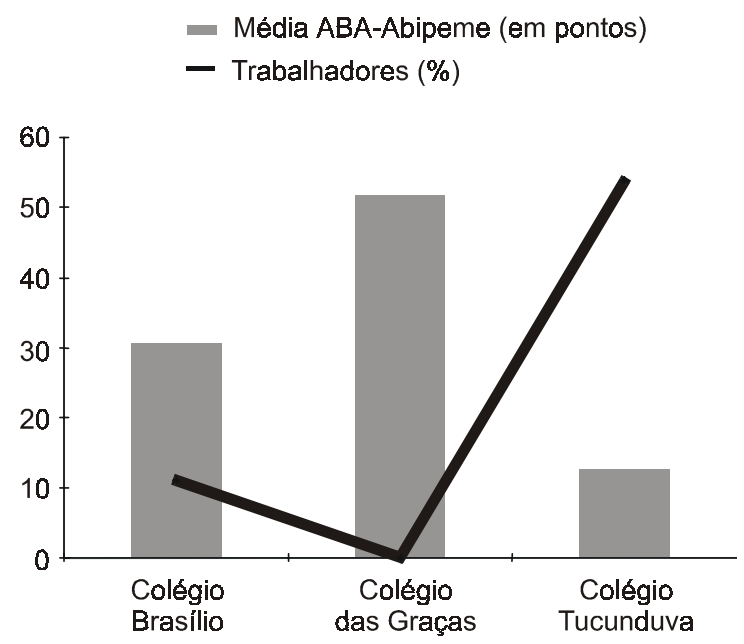

Fonte: Pesquisa realizada pelo autor (Souza, 1997).

(1) $O$ critério ABA-Abipeme varia de 0 a 87 pontos. Baseia-se na posse de bens (banheiro, rádio, TV, máquina de lavar roupa, aspirador de pó, automóvel), número de empregadas domésticas mensalistas e nível de escolaridade do chefe econômico do domicílio.
Na caracterização da moradia, buscou-se detectar a apropriação de bens não apenas enquanto objetos de distinção, no sentido de fator de diferenciação econômica e social, mas também como objetos simbólicos mais valorizados e em relação à exposição às mensagens audiovisuais.

Os adolescentes da Escola das Graças mantêm elevada posse de bens, relativamente superior aos da Escola Brasílio e muito mais em relação aos da Escola Tucunduva, em itens como automóvel, fac-símile, computador e TV por assinatura/cabo. Entretanto, no que diz respeito a rádio, TV e aparelho de compact disc, os percentuais são elevados nas três escolas. Neste aspecto, concorda-se com Helena Abramo, que aponta a música como um dos componentes mais significativos para parcela daquele público. A música "está presente e acompanha quase todos os momentos de lazer: o tempo em que se fica sozinho em casa, o encontro com os amigos, as festas e, principalmente, os bailes" (Abramo, 1994:66).

Para os jovens de classe média, como os da Escola Brasílio, ou para aqueles de classe alta, como os da Escola das Graças, a apropriação de bens - dentre estes os eletroeletrônicos como rádio, $\mathrm{TV}$, aparelho de $\mathrm{CD}$, videocassete e computadores - decorre de seu nível socioeconômico. Já para o adolescente da Escola Tucunduva, isto é propiciado pelo sistema de crediário, que, de acordo com Abramo, constitui-se, a partir da reforma financeira de 1968, "fator importante para a inserção das camadas populares nesse universo de consumo de bens culturais", facilitando assim "a compra de eletroeletrônicos, principalmente aparelhos de televisão e de reprodução sonora".

Para a autora, "os artigos da indústria cultural, como discos, fitas, revistas de entretenimento, filmes, têm seu maior público entre os jovens, para quem passam a ser preferencialmente dirigidos" (Abramo, 1994:61).

Dada a importância que o lazer desempenha na sociabilidade do público adolescente-juvenil, procurou-se identificar quais das atividades a ele relacionada obteriam suas escolhas. As três preferências de lazer que tiveram maior destaque, considerando-se as respostas em relação à amostra, foram: visita à casa de amigos $(70,5 \%)$; show $(42,1 \%)$; e danceteria $(37,9 \%)$.

A atividade de lazer, em todos os estudos sobre os jovens, é apontada com destaque. Para Abramo (1994: 61-62), o lazer "aparece como um espaço especialmente importante para o desenvolvimento de relações de sociabilidade, das buscas e experiências através das quais procuram estruturar suas novas referências e identidades individuais e coletivas - e é um espaço menos regulado e disciplinado que os da 
escola, trabalho e da família. O lazer se constitui também como um campo onde o jovem pode expressar suas aspirações e desejos e projetar um outro modo de vida".

Chamou a atenção, nos resultados da pesquisa, a importância obtida pelo item visita à casa de amigos. "De fato, para a generalidade dos jovens, os amigos de grupo constituem o espelho de sua própria identidade, um meio através do qual fixam similitudes e diferenças em relação a outros.

Paralelamente, os grupos de amigos aparecem como uma instância de proteção de identidades individuais. As socializações a que os jovens se encontram sujeitos são muito diversificadas. Por isso, é possível admitir que uma das funções essenciais dos grupos de amigos seja não tanto a de desafiar os valores da família ou das gerações mais velhas, mas assegurar aos jovens uma proteção aos assaltos socializantes a que estão sujeitos" (Pais, 1997:94).

Também destacaram-se, por ordem de preferências, os shows, danceterias e espaços esportivos. A adesão generalizada dos jovens a tais atividades deve ser entendida não apenas do ponto de vista instrumental, mas também do simbólico.

Quando considerado o lazer separadamente para homens e mulheres, verificam-se algumas preferências evidentes para o sexo feminino e outras para o masculino.
Assim, as opções tais como show, danceterias e cinema aparecem principalmente para as mulheres, enquanto espaços esportivos são mais citados pelos homens.

A importância do lazer para os jovens fez com que os salões de dança surgissem nas periferias e as danceterias nos bairros centrais, além das casas de diversões eletrônicas, lanchonetes, etc. (Abramo, 1994:60).

Entre os participantes da pesquisa, $61,1 \%$ afirmaram desenvolver alguma outra atividade nos finais de semana, destacando-se estudar e viajar (ambas com 16,1\%), prática esportiva $(14,3 \%)$ e namoro $(12,5 \%)$. Dos adolescentes da Escola das Graças, nenhum utiliza os fins de semana para estudar, sendo uma atividade desenvolvida mais pelos alunos da Escola Brasílio. Viajar é mais um privilégio dos alunos da Escola das Graças.

Chamou a atenção, ainda, que apenas um dos pesquisados afirmou ter como opção de lazer idas aos shoppings. Sabese que, atualmente, os shoppings transformaram-se em áreas de lazer para os adolescentes e uma das maneiras deles se informarem a respeito dos produtos destinados à sua faixa etária. Estes centros comerciais, além de apresentarem uma série de jogos eletrônicos, ringues, boliche, produtos esportivos, lanchonetes, etc., oferecem certa segurança. Por outro lado, "a extraterritorialidade do shopping também fascina as pessoas muito jovens ainda, justamente pela possibilida-

\section{GRÁFICO 2}

Distribuição de Exposição à Mídia, segundo Veículos de Massa

Região Metropolitana de São Paulo - 1997

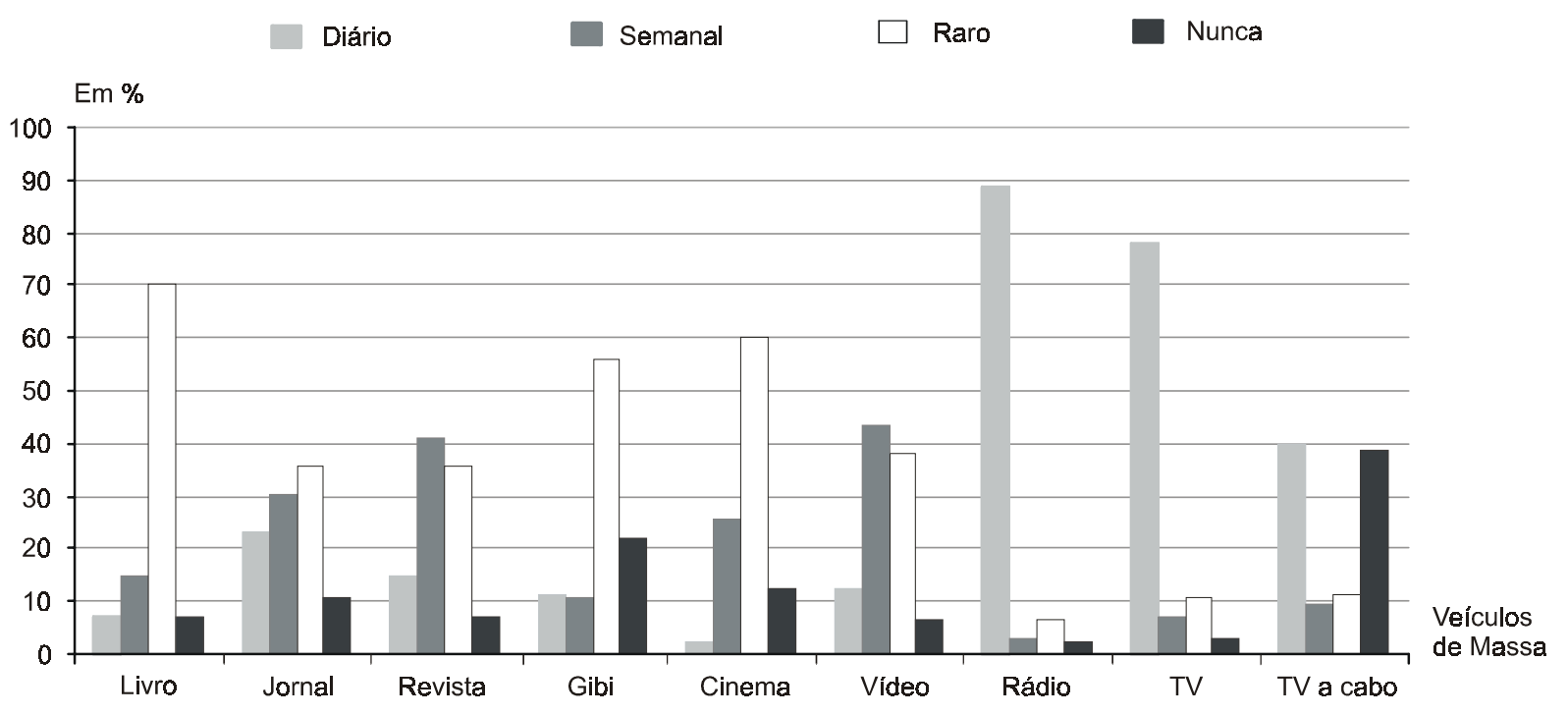

Fonte: Pesquisa realizada pelo autor (Souza, 1997). 
de de uma deriva no mundo dos significantes mercantis" (Sarlo,1997:21). Isto, inclusive, foi detectado pelo Estudo qualitativo sobre a imagem da marca Rainha, preparado pela Leo Burnett Publicidade: os jovens tomam contato com as novidades em tênis "principalmente através do que vêem nos pés dos jovens da sua idade e nas vitrines dos shoppings", ${ }^{3}$ além da troca de informações entre eles e pelas propagandas da TV.

O veículo de comunicação ao qual o jovem tem mais acesso é o rádio, pois $88,4 \%$ afirmaram ouvi-lo diariamente, seguido pela TV convencional $(77,9 \%)$ e a cabo $(40 \%)$. Os demais meios de comunicação e informação situam-se entre o semanalmente ou raramente. $\mathrm{O}$ vídeo aparece com $43,2 \%$ de assistência semanal e 37,9\% raramente. Os maiores percentuais de raramente couberam à leitura de livros (70,5\%), cinema (60\%) e leitura de gibi $(55,8 \%)$.

Do total de entrevistados, 97,9\% afirmaram assistir às publicidades, independentemente, portanto, de classe social ou gênero.

Observando o Gráfico 3, percebe-se que, entre os jovens da Escola das Graças (classe A), as publicidades referentes a refrigerante e alimento obtiveram maior destaque. Ves- tuário e calçado/tênis salientaram-se na preferência da Escola Brasílio (classe B) e da Escola Tucunduva (classe C). Tais resultados reportam, novamente, ao trabalho de Helena Abramo em dois aspectos detectados pela autora. Primeiro, para os adolescentes dos estratos de baixa renda, "a participação na vida urbana, os deslocamentos impostos pelas atividades de trabalho e instrução, a busca de diversão para além dos limites do bairro, levaram a um aumento de circulação dos jovens pelos variados espaços da cidade, intensificando bastante a sua exposição pública. A importância da roupa está intimamente vinculada a esta exposição, na medida em que dá visibilidade às identidades sociais" (Abramo, 1994:69).

Um segundo aspecto seria o aumento, a partir da década de 70, de "exposição dos jovens das camadas trabalhadoras aos meios de comunicação e aos apelos da publicidade. Esse fenômeno gera, entre outras conseqüências, a absorção dos padrões estéticos dos setores mais ricos, baseados no consumo de determinados tipos de mercadorias que sinalizam essa condição social, cujo modo de vida é almejado e cujos apelos encontram eco na pequena - mas real - capacidade aquisitiva desses jovens" (Abramo, 1994:70/71).

\section{GRÁFICO 3}

Publicidades Preferidas, segundo a Escola

Região Metropolitana de São Paulo - 1997

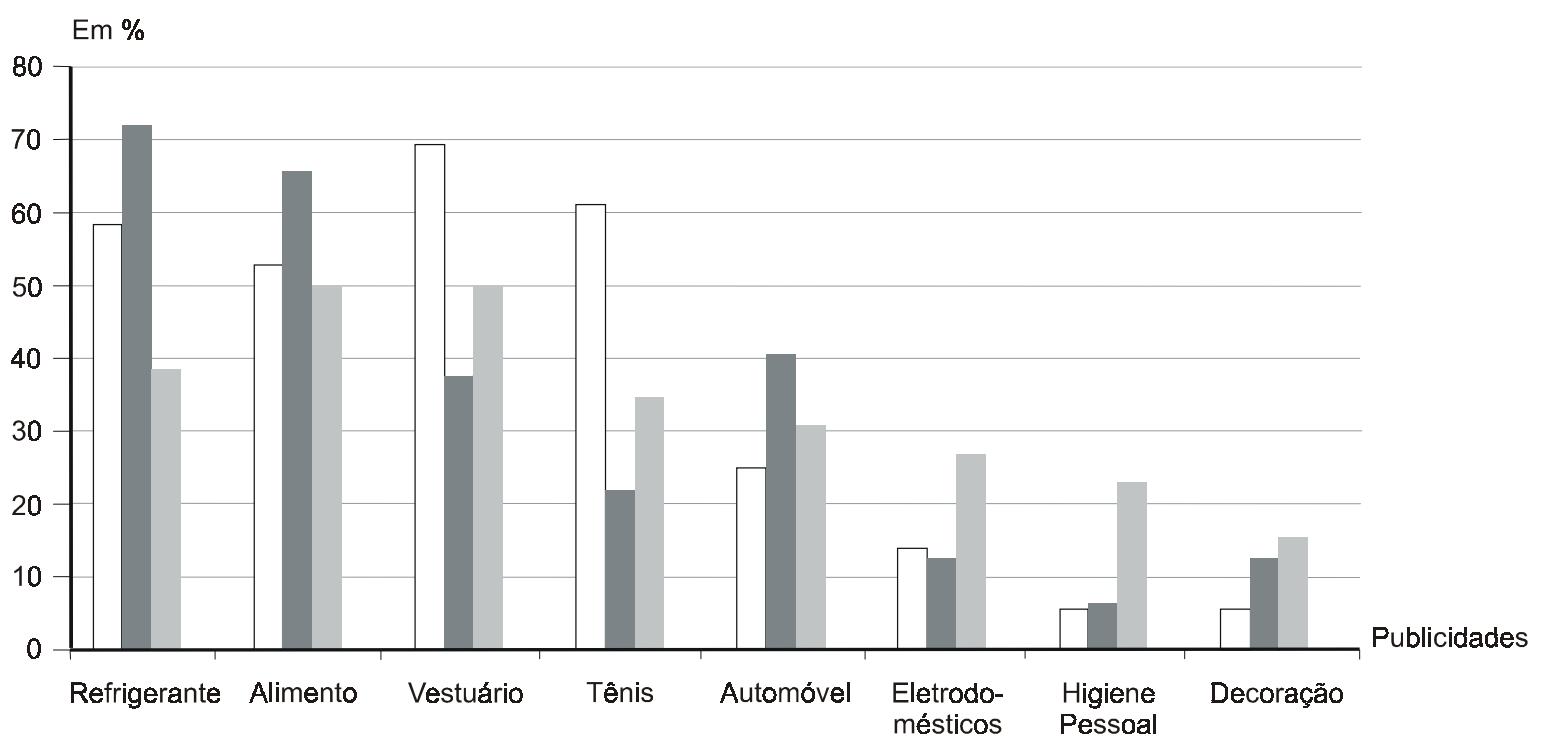


Dentre o total dos pesquisados, 41,5\% afirmaram que a publicidade contribui para a sua formação, $24,5 \%$ disseram que não e $34 \%$, às vezes. O maior percentual de respostas afirmativas coube às mulheres $(64,1 \%)$. Por instituição, 69,2\% dos alunos da Escola Tucunduva, 40\% da Escola Brasílio e 21,2\% da Escola das Graças afirmaram que a propaganda interfere na sua formação. Pelos resultados, acredita-se que o nível sociocultural seja um fator determinante para uma postura mais crítica em relação à publicidade (Gráfico 4).

A partir do momento em que a mídia, sobretudo a televisiva, impõe modelos estéticos a serem seguidos, sinalizando inclusive uma condição socioeconômica, e associados a um modelo de cidadania, isso torna-se preocupante, pois, segundo Mattelart (1994:116), "se os homens nascem iguais diante da lei, eles não nascem iguais diante do mercado e essa desigualdade coloca constantemente em perigo o exercício da soberania do cidadão e dos povos".

Como foi visto, a publicidade é um modelo de referência. Talvez isto seja explicável pelo fato de que "os publicitários, consciente ou inconscientemente, gradualmente reconhecem a complexidade do modo de vida urbano, especializado, interdependente, que cria um resíduo de necessidades desencontradas. Percebendo o vácuo na orientação das relações pessoais, eles começam a ofe-

\section{GRÁFICO 4}

Percepção da Interferência da Publicidade Televisiva na Formação, segundo a escola

Região Metroplitana de São Paulo - 1997
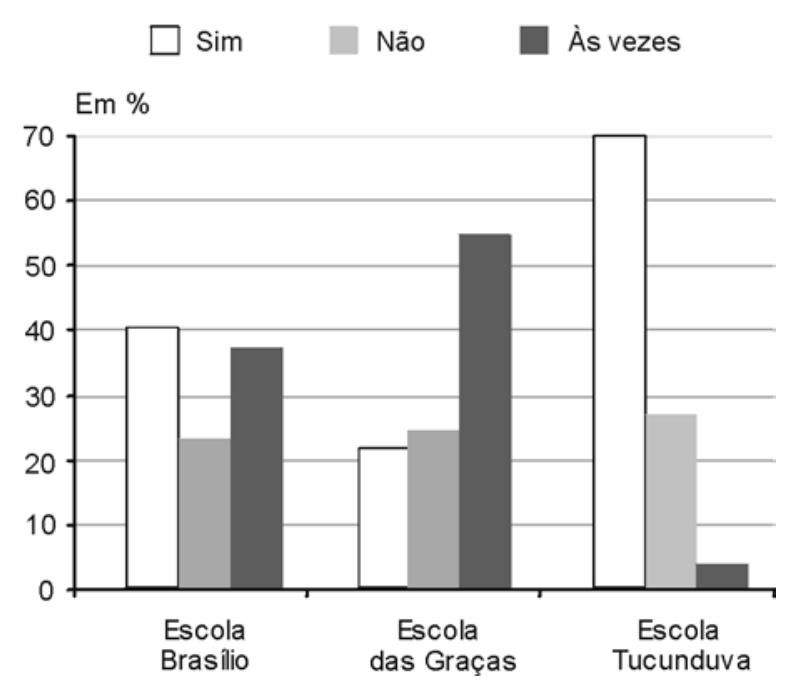

Fonte: Pesquisa realizada pelo autor (Souza, 1997). recer seus produtos como resposta para o descontentamento moderno"(Marchand apud Ortiz, 1994:120). Daí Renato Ortiz (1994:120) afirmar que "a publicidade adquire assim um valor compensatório e pedagógico".

Por outro lado, para a absorção de um público mais amplo, tanto os produtores quanto as empresas de propaganda, destacadamente aquelas voltadas para o mercado globalizado, procuram universalizar suas mensagens publicitárias, evitando tudo que é "tópico, local ou étnico demais". No caso da Coca-Cola, deve-se evitar ainda contrariar quaisquer grandes correntes culturais, e para tanto os eventos a serem patrocinados devem ser os que despertam interesses universais, tais como os de música e esporte, visando especialmente o público jovem.

Em relação à publicidade dirigida ao público adolescente-juvenil, dois outros fatores devem ser acrescentados: primeiro, os conteúdos transmitidos estão baseados em valores, atitudes, comportamentos, padrões estéticos, etc. detectados, aprioristicamente, por meio de sondagens qualitativas ou mesmo quantitativas, elaboradas pelas agências publicitárias; segundo, o próprio meio televisivo possibilita a transmissão de uma mensagem que conta com um dos recursos altamente valorizados por eles, ou seja, a imagem, que na pesquisa realizada foi um dos elementos que mais os atraiu $(69,5 \%)$. Somem-se a isso a música e os sons, ingredientes perfeitos para a obtenção de uma grande receptividade.

Verifica-se, portanto, que os executivos das empresas, em consonância com o trabalho das agências publicitárias, efetivamente desempenham o papel de "intelectuais", considerando-se que seus técnicos e profissionais apropriam-se cada vez mais dos saberes sociológico, antropológico, psicológico, etc., no sentido de produzir "um saber empírico que lhes permite estabelecer uma mediação entre o pensamento e os interesses políticos e econômicos de suas empresas" (Ortiz, 1994:148). Exemplificando, pode-se citar a Coca-Cola, que, criada em 1886 como medicamento de fórmula secreta e com 99\% de água açucarada, conseguiu em um século de existência transformar-se em símbolo ocidental de vida e fazerse representar em 185 países.

Deve-se considerar, ainda, que o jovem, enquanto ator social e consumidor, reelabora as mensagens publicitárias, em decorrência de sua subjetividade. Entretanto, o que se nota na pesquisa é que, embora as reinterpretações apresentem algumas nuanças, em face da objetividade e do "didatismo" colocados na maioria das peças publicitárias, estas são corretamente interpretadas. Por outro lado, a identificação com os conteúdos, valores, padrões estéticos das 
imagens, personagens, música, sons e cenários que compõem o contexto publicitário não é suficiente para que a maioria dos jovens associe-se com os personagens e estilos de vida retratados nos filmes. Neste aspecto, os representantes da classe social $\mathrm{C}$ foram os que mais se identificaram $(42,3 \%)$, além de acharem que a publicidade contribui para a sua formação $(69,2 \%)$. Assim, como já mencionado, o nível sociocultural é fator importante para uma postura crítica em relação às mensagens publicitárias.

De uma forma geral, entretanto, nota-se que a categoria adolescente-juvenil, independentemente da origem de classe, de seu nível de renda e de sexo, conforme foi sinalizado, é sensível e receptiva à publicidade. No contexto brasileiro, dada a significância deste segmento populacional, as indústrias, destacadamente as de alimento, refrigerante, vestuário e tênis, têm direcionado seus esforços promocionais para este público.

$\mathrm{Na}$ tentativa de se verificar a reelaboração que os jovens fazem das publicidades, foram exibidos em vídeo 12 comerciais selecionados, sendo seis da Coca-Cola e seis do Tênis Rainha. Ressalta-se, porém, que o contexto em que os adolescentes assistiram às peças publicitárias é bastante diferente daquele que se vivencia diante de um canal televisivo, com um movimento alternado de imagens ao qual Raymond Williams se referiu como um "fluxo irresponsável de sentimentos e imagens (Williams, 1975:89/93). No período de uma aula (45 minutos), os entrevistados, além de responderem ao questionário, estiveram também como telespectadores e ainda opinaram sobre os filmes a que assistiram. Diferentemente, portanto, de seus hábitos de assistir à TV.

Após a projeção de cada publicidade, os jovens escreviam sobre o que acharam ou entenderam do filme. Para se ter uma idéia de como ocorreu a reelaboração e interpretação das mensagens, são descritos dois dos comerciais analisados, bem como apresentadas as opiniões mais significativas obtidas junto aos receptores.

Antes de expor as questões levantadas, serão feitos alguns comentários sobre as publicidades selecionadas e uma pequena síntese de cada uma delas. Os títulos dos comerciais seguem a mesma designação dada pelo Arquivo de Propaganda, ou seja, "Nova Coca-Cola 600ml" e "Cabeça (Tênis Rainha)".

\section{Propaganda da Coca-Cola: Nova Coca-Cola 600ml}

Imagens: um close-up da garrafa da "Nova Coca-Cola $600 \mathrm{ml}$ ". Garrafa girando e a voz do locutor. Após os fla- shes iniciais acelera-se o ritmo da música, em inglês. Um coro misto canta: "Agarra ela! Amassa ela! Passa a mão nela! Fica com ela! etc.” A cada uma destas expressões, a garrafa é enfocada com alguém e, ao mesmo tempo, jovens casais correspondem em atitudes, embora discretamente, ao refrão do que é dito. Outros flashes evidenciam a garrafa saindo de um congelador, esborrifando água e gelo. Tudo isto intercalado com cenas juvenis românticas, de namoro e algumas próximas ao erotismo. Encerra-se o comercial com jovens ladeando uma garrafa de tamanho desproporcional.

Para analisar o texto deste comercial, procurou-se detectar a relação entre significantes, significados e sua inserção no todo publicitário, pois, "se usamos o mesmo significante para significar uma realidade diferente daquela a que originalmente ela se refere, duas consequiências podem ocorrer: ou se altera o significado, ou se altera a realidade" (Soares, 1976:152). Assim, o jogo entre a garrafa e os jovens e a utilização de palavras e expressões como "Sente ela! Pega ela! Beija ela! sofreram conotações de significados que representam outra realidade. Desta forma, ao se atribuir a determinado "material lingüístico certa intencionalidade, o processo social de apropriação da linguagem descarta a rede de significações dadas ao nível da língua e o enreda por conceito/ valores" (Miceli, 1972:76). Parafraseando Miceli, podese dizer: sofreram "filtragem deformadora" e dispõem de "autonomia mítica".

Quanto ao comercial citado, cabem duas observações: a primeira é que, apesar de denotar nele certo erotismo, a Coca-Cola mantém sua tradição de evitar cenas de sexualidade nos anúncios; a segunda diz respeito à embalagem descartável, amplamente divulgada em agosto de 1995, data em que o comercial fora veiculado, evidenciando a despreocupação da empresa com o lixo sólido. O protesto efetuado pelo movimento ecologista em 1970, nos Estados Unidos, por este mesmo motivo, em frente à sede da companhia, ainda não se constitui em preocupação da empresa, pelo menos no Brasil.

Retornando à pesquisa, nota-se que a "filtragem deformadora" foi detectada pelos adolescentes e a freqüência maior das respostas manteve-se na relação "refrigerante-namoro-sexualidade". Para exemplificar, citam-se apenas algumas respostas apresentadas: Para você gostar da Coca-Cola, fazer com a Coca-Cola o que você faz com sua namorada (Colégio Brasílio, sexo masc., 15 anos); Que ela é gostosa como a mulher ou o homem, atração entre o casal (Colégio Brasílio, sexo fem., 14 anos); Eles comparam 
a Coca-Cola como sendo uma mulher (Colégio das Graças, sexo masc., 15 anos); Mostrar que o produto é tão bom quanto ficar, abraçar...Compre! (Colégio das Graças, sexo fem., 14 anos); Juntando a sensualidade da mulher de ficar com o homem ligado à Coca-Cola (Colégio Tucunduva, sexo fem., 18 anos); Relação namoro (sexo) com o produto (Colégio Tucunduva, sexo masc., 34 anos).

\section{Propaganda do Tênis Rainha: Cabeça}

Primeira cena: busto de mulher na lateral. Segunda cena: homem com tórax despido. $\mathrm{O}$ foco da câmera retorna à mulher, que passa sua mão pela cabeça. As imagens se sucedem, ora com a mulher, ora com o homem, separadamente. Olhares lânguidos trocados, belos corpos em movimento. Projeta-se, sobreposta à figura da mulher, a expressão " $O$ quê"; em seguida a imagem do homem é encimada por "você tem"; finalmente, vem a expressão "na cabeça?". Não há resposta para a pergunta. Estas imagens são acompanhadas por um fundo musical. Encerrando o comercial, surge uma cena em que o tênis é focalizado e outra indagação por escrito: "E nos pés? Rainha".

De todos os comerciais apresentados na Escola Brasílio, este foi o que obteve maior número de críticas (cinco) ou de respostas como Não entendi (cinco); Como se a pessoa só pensasse no prazer, e em ter um bom tênis (idiota) (sexo fem., 14 anos); Nada a ver com o produto"(sexo fem., 14 anos); $O$ que você tem na cabeça? Muito sem sentido, é um absurdo essa associação (sexo fem., 14 anos); Muito vulgar (sexo fem., 14 anos); Que comercial cretino, a cabeça com os pés, não tem nada a ver (sexo fem., 16 anos). Curioso é que, do total de 22 alunas, dez optaram por tais respostas. Considerando que a referida publicidade seja, efetivamente, "apelativa", mas que muito das outras apresentadas também o foram, talvez caiba indagar se tais afirmativas não estariam relacionadas a uma moral conservadora arraigada em parte da cultura feminina da classe média.

Dentre os demais adolescentes, independentemente do sexo, a interpretação do filme foi assim: Na cabeça, você só pensa em mulher, e nos pés no Rainha (sexo masc., 15 anos); O homem tem a mulher na cabeça e vice-versa. Nos pés só Rainha (sexo fem., 14 anos); Podemos também considerar o que usamos no pé, tão importante como o que usamos na cabeça, nesse caso, devemos usar Rainha (sexo fem., 15 anos); Na cabeça uma bela mulher, nos pés um tênis Rainha (sexo masc., 28 anos); Mesmo nas horas $H$ ele pensa no Rainha (sexo fem., 16 anos).
É de fundamental importância aprofundar as análises da publicidade, uma vez que ela, enquanto modelo cultural, além de apresentar uma produção volumosa e constante, "tem como projeto 'influenciar', 'aumentar o consumo', 'transformar hábitos', 'educar' e 'informar', pretendendo-se ainda capaz de atingir a sociedade como um todo" (Rocha, 1990:26).

\section{EDUCAÇÃO E PUBLICIDADE}

O objetivo da publicidade alterou-se com o tempo. Hoje, além da venda de produtos, serviços e bens simbólicos, ela demonstra modelos a serem seguidos, apresentando, desta forma, um objetivo explícito, que consiste em oferecer as vantagens de determinados produtos, e um objetivo implícito, por intermédio do qual flui sua ação pedagógica. Por meio desta ação, a publicidade propõe transmitir valores sociais e pessoais, penetrando, inclusive, no mundo da política e tornando-se um modelo de referência, ao veicular um padrão estético sinalizador de um status social, bem como um modelo de cidadania - "quem não o ostenta é imediatamente jogado para o campo dos desqualificados para o convívio social, sob a suspeita de marginalidade ou de delinqüência, ou simplesmente pela demonstração de incapacidade para o consumo" (Abramo, 1994:73).

Se a publicidade, além de transmitir valores sociais e pessoais e de se constituir em modelo de referência, tem ainda a função "de demonstração de modelos a serem seguidos, isto é, a apresentação de padrões físicos, estéticos, sensuais, comportamentais, aos quais as pessoas devem se amoldar" (Marcondes Filho, 1992:77), ela efetivamente desenvolve uma ação pedagógica. Tais considerações reportam aos resultados da pesquisa: $77,9 \%$ dos adolescentes assistem TV convencional e $40 \%$ a cabo, diariamente, em contrapartida aos maiores percentuais de raramente que couberam à leitura de livro (70,5\%); 97,9\% afirmaram assistir as publicidades, independentemente, portanto, de classe social ou gênero; do total dos pesquisados, $41,5 \%$ (de acordo com o nível socioeconômico, têm-se $69,2 \%$ nos adolescentes de padrão C; $40 \%$ no B e $21,2 \%$ no A) disseram que a publicidade contribui para a sua formação e 34\% acharam que "às vezes" ela contribui; $18,4 \%$ (50\% público B; $35,7 \%$ A e 14,3\% C) apontaram como aspectos negativos dos comerciais televisivos a manipulação; e 27,4\% (42,3\% para os adolescentes de nível C; 30,8\% para os de nível B e 26,9\% para os de nível A) acham que os jovens retratados nos filmes publicitários correspondem à sua realidade de vida. Com isso, pode-se afirmar que “(...) a educação 
não está restrita aos processos desenvolvidos apenas no interior da instituição escolar. De maneira mais ampla, compreende-se que em toda a sociedade são encontrados mecanismos educativos que produzem conhecimentos, pedagogias e formas de ensinar; muitos desses mecanismos podem ser encontrados em produções culturais como filmes, novelas, histórias em quadrinhos, publicidade, só para citar alguns" (Sabat, 1999:1). A influência da publicidade, entretanto, incide com maior intensidade junto aos adolescentes de nível socioeconômico C.

Os jovens das camadas populares, como foi possível verificar, são oriundos de famílias que apresentaram também o menor nível de escolaridade, sendo que, na pesquisa, $50 \%$ das mães não completaram o ensino básico e $26,9 \%$ eram analfabetas. Neste aspecto, quando se relaciona a interpretação das publicidades com o poder aquisitivo do jovem, acredita-se, como Bárbara Freitag (1987:9), que "as condições materiais de vida não condicionam apenas os conteúdos (concepção de mundo), mas as próprias estruturas formais que possibilitam criar ou assimilar esses conteúdos".

Deve-se registrar, ainda, que, entre os fatores que mais atraíram o público juvenil, no que diz respeito às publicidades, destacam-se as imagens, com 69,5\% das preferências. Os motivos das escolhas deveram-se, dentre outros, ao fato de apresentarem tudo muito perfeito $(41,4 \%)$ e às personagens $(15,7 \%)$. Embora "a publicidade não invente coisas" e que "seu discurso e suas representações estão sempre relacionados com o conhecimento que circula na sociedade" (Sabat, 1999:5-6), não se pode deixar de ter claro que: "A construção de imagens que valorizam determinado tipo de comportamento, de estilo de vida ou de pessoa é uma forma de regulação social que reproduz padrões mais comumente aceitos" (Sabat, 1999:1-2).

Por outro lado, como afirmado anteriormente, as produções culturais, dentre estas, a publicidade, constituemse em mecanismos educativos. Neste artigo, foram analisadas aquelas publicidades apresentadas no veículo midiático de maior recepção junto aos adolescentes, ou seja, a televisão. Assim, deve-se "buscar uma complementaridade entre as diferentes estruturas cognitivas e perceptivas que a linguagem da televisão e da escola estimulam: a primeira, audiovisual, estimula mais a percepção intuitiva; a segunda, predominantemente verbal e escrita, privilegia o pensamento e a razão. Essas particularidades do espaço cultural televisivo e escolar precisam ser consideradas por aqueles que se preocupam em estabelecer relações entre a educação formal e os produtos culturais difundidos pelos meios de comunicação de massa. Não se deve procurar igualar, reduzir um ao outro, nem privilegiar um em detrimento do outro" (Franco, 1999:12).

A pesquisa foi aplicada junto aos jovens de três níveis socioeconômicos que freqüentavam a primeira série do ensino médio. O que dizer, entretanto, sobre as mensagens publicitárias recebidas por significativos percentuais da população vivendo em condições precárias, em um país marcado pelas desigualdades sociais, no qual o aparato escolar ainda não atingiu a excelência democrática do Primeiro Mundo e onde os meios de comunicação, muitas vezes, funcionam como uma escola paralela? Finalizando, afirma-se ser de fundamental importância uma análise crítica em relação à TV não somente no que diz respeito às publicidades, "como também em relação aos filmes, telenovelas, noticiários, consumismo esportivo, etc., e, inclusive, sobre os outros meios de comunicação (imprensa, rádio, cinema, etc.)"(Souza, 1997:101). Uma das formas de se atingir tais objetivos poderá ser através da instituição escolar. A ela competirá um maior e mais importante papel no processo de formação de um telespectador crítico em face da mídia televisiva. "Ambas, escola e televisão, contribuem para o processo educacional, já que transmitem uma concepção de homem e sociedade. A primeira, de modo a apresentar os conhecimentos de uma maneira sistematizada e formal, por exercer uma ação pedagógica especializada e a segunda, não sistematizada e informal" (Souza, 1997:100).

\section{NOTAS}

1. Este trabalho contém partes da tese de doutorado Publicidade e contemporaneidade: estilos de vida e juventude (Souza, 1998).

2. As faixas etárias que caracterizam os adolescentes e jovens não apresentam a mesma freqüência de idade em todos os trabalhos. Para exemplificar, cita-se pesquisa realizada pelo "Research International Observer", cuja amostra constou de 112 grupos de discussão, em 27 países, e foi denominada de "Adolescentes do mundo", colocando este grupo etário na faixa de 13 a 18 anos. "The Kids are uptight" (Campaign, 13/05/94). De acordo com o Estatuto da Criança e do Adolescente, Lei no ${ }^{\circ} .069$, de 13/jul./90, Livro I, Parte Geral, Título I, Art. 2º̣, adolescente é a pessoa "entre doze e dezoito anos de idade". Para este artigo, consideram-se adolescentes aqueles na faixa etária definida por esse Estatuto.

3. O estudo foi realizado por meio da técnica de discussão em grupo, realizada em São Paulo, nos dias 26, 27 e 28 de setembro 1990, com jovens do sexo masculino, entre 11 e 17 anos, das classes $\mathrm{AB}+$ e $\mathrm{B}-\mathrm{C}+$ que utilizavam diariamente tênis e que tivessem comprado pelo menos um par, nos últimos quatro meses Leo Burnett Publicidade (1990:10).

\section{REFERÊNCIAS BIBLIOGRÁFICAS}

ABRAMO, H.W. Cenas juvenis - punks e darks no espetáculo urbano. $1^{\mathrm{a}} \mathrm{ed}$ São Paulo, Ed. Página Aberta Ltda., 1994. 
ANDREOTI NETO, N. (org.). Estatuto da criança e do adolescente. Lei nº 8.609, 13/jul./90. São Paulo, Coleção de Leis Rideel, 1991.

CAMPAIGN. Editora Haymarket, 13/05/94 (tradução de Lúcia Maria Lopes).

FRANCO, A.P. "Televisão, ensino de história e pluralidade cultural: (re)pensando relações”. Texto apresentado na 22를 Reunião Anual da Associação Nacional de Pós-Graduação e Pesquisa em Educação (Anped), set. 1999.

FREITAG, B. Política educacional e indústria cultural. São Paulo, Cortez, n.26, 1987 (Coleção Polêmica de Nosso Tempo).

LEO BURNETT PUBLICIDADE. Estudo qualitativo sobre a imagem da marca Rainha. São Paulo, set. 1990.

MARCONDES FILHO, C. Televisão: a vida pelo vídeo. 8aed. São Paulo, Ed. Moderna, 1992 (Coleção Polêmica).

MARTÍN-BARBERO, J. “América Latina e os anos recentes: o estudo da recepção em comunicação social.” In: SOUSA, M.W. de (org.). Sujeito, o lado oculto de receptor. São Paulo, USP/ECA/Brasiliense, 1995.

MATTELART, A. "Les regards critique." La publicité. Paris, La Découverte, 1994, p.106-117 (tradução de Paulo Goya).

MEIO \& MENSAGEM. São Paulo, ano XIX, n.745, 24/02/1997.
MICELI, S. A noite da madrinha. São Paulo, Perspectiva, 1972.

ORTIZ, R. Mundialização e cultura.1a ed. São Paulo, Brasiliense, 1994.

PAIS, J.M. Culturas juvenis. Lisboa-Porto-Coimbra, Imprensa Nacional Casa da Moeda, 1997.

ROCHA, E.P.G. Magia e capitalismo - um estudo antropológico da publicidade. $2^{\mathrm{a}}$ ed. São Paulo, Brasiliense, 1990.

SABAT, R. "Gênero e sexualidade na pedagogia da mídia". Texto apresentado na 22를 Reunião da Anped, set. 1999.

SARLO, B. Cenas da vida pós-moderna: intelectuais, arte e videocultura na Argentina. Rio de Janeiro, Editora UFRJ, 1997.

SOARES, M.B. “A linguagem didática”. In: NAGLE, J. (org.). Educação e linguagem. São Paulo, Edart, 1976.

SOUZA, L.C.C. de F. e. Propaganda de brinquedos e educação pela TV. Taubaté, Vogal Editora, 1997.

Publicidade e contemporaneidade: estilos de vida e juventude. Tese de Doutorado. Pontifícia Universidade Católica de São Paulo, 1998.

VEJA. São Paulo, n.1.388, 19/04/1995.

WILLIAMS, R. Television - technology and cultural form. New York, Schoken Books, 1975. 